\title{
The importance of theoretical underpinning for a school mathematics curriculum: The Ghanaian experience
}

Ampadu, Ernest $\searrow$
Richmond University, UK (Ernest.ampadu@richmond.ac.uk)

Adofo, Stephen

Buduburam Basic School, Ghana (adofo_1980@yahoo.co.uk)

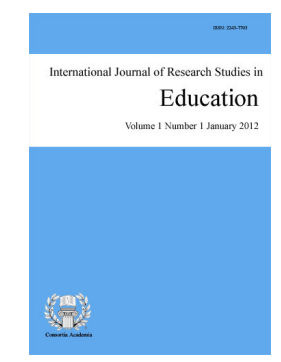

ISSN: 2243-7703 Online ISSN: 2243-7711

OPEN ACCESS

\section{Abstract}

The teaching and learning methods used in mathematics classrooms are increasingly being questioned for their effectiveness. In view of this, the mathematics curriculum in Ghana like in most other countries has undergone a number of restructuring with the aim of improving the teaching and learning of the subject. This paper aims to discuss issues related to mathematics education in Ghana. The paper begins with a historical overview of the Ghanaian Junior High School (JHS) mathematics curriculum. It provides an analysis of the restructuring JHS curriculum under the two broad theoretical backgrounds in mathematics education: behaviourism and constructivism. Analysis of the JHS curriculum and other research work suggest that the role of the teacher in mathematics classroom goes beyond acting as a facilitator in the teaching and learning process and students still rely on the teacher as their main source of knowledge acquisition. The authors take the position that mathematics education at the JHS level and in Ghana as a whole must redefine its goals and theoretical background; where the teacher and the student play an active role in the teaching and learning process. In view of this, the authors propose the enactivist theory, which advocates for partnership between teachers and students in the classroom, as the new paradigm for teaching and learning that must be considered within the Ghanaian context.

Keywords: curriculum; behaviourism, constructivism; enactivism; mathematics education 


\section{The importance of theoretical underpinning for a school mathematics curriculum: The Ghanaian experience}

\section{Introduction}

The teaching and learning of mathematics in Ghanaian schools, as in most other countries, is prescribed by the national curriculum which aims at providing equal learning opportunities for all students (Nabie \& Kolorah-Ekpale, 2004; Kuwayama, Davis, Ampiah, \& Kwabla, 2007). These school curricula have undergone numerous restructuring and changes over the last four decades with the prime motive of improving the teaching and learning of mathematics. These changes in the school mathematics curricula have been informed by the important role that mathematics plays in our daily lives as argued by Keith (2000) and Blum (2002). In addition to this, the falling standards of students' achievements in mathematics and students declining interest in mathematics over the years have also necessitated for the introduction and implementations of some of these new school curricula

In Ghana, research by Eshun-Famiyeh (2005) established that despite the important role that effective knowledge in mathematics plays in both personal and national development, mathematics continues to be the most difficult subject in the school curriculum; at all levels of Ghana's education system and this general perception is reflected in students' performance over the years. For example, a Criterion Reference Test (CRT) conducted in 1996 and 2000 in Ghana established that only 1.8\% and 4.4\% of primary year six students' nationwide obtained a mark of 55\% (MoE, 2002). Furthermore, the results from the Trends in International Mathematics and Science Study (TIMMS) conducted for junior secondary year two (grade 8) students in 2003 portrayed a generally poor performance on the part of Ghanaian students, with students' scoring an average of 276 in mathematics, which was significantly lower than the international average of 467 (UEW/GES, 2003). Similarly, the 2007 and 2011 TIMMS mathematics average score of 309 and 331 respectively for grade 8 students from Ghana were lower than the low international benchmark average of 400 (Mullis, Martin, \& Foy, 2008; Mullis, Martin, Foy, \& Arora, 2012).

In view of these challenges among others, a new mathematics curriculum was introduced into Ghanaian pre-tertiary education system in September 2007. The main rationale for the 2007 mathematics curriculum at the Junior High School (JHS) level is to help all Ghanaian young persons to acquire the mathematical skills, insight, attitudes and values that they will need to be successful in their chosen careers and daily lives" (MOES, 2007, p. ii). Although there is no consensus as to what constitutes good mathematics teaching and learning practices in Ghana, the 2007 curriculum offers new ideas and directions based on the principles of constructivism. The principles and guidelines of this new curriculum reflect research recommendations and theoretical shifts and changes in the teaching and learning strategies for mathematics at the international level and across most countries as indicated by Potari and Georgiadon-Kabouridis (2009). However, although the principles of this new curriculum voice a student centred approach to teaching, these principles are not recognised in the objectives explicitly, and suggested activities in the curriculum documents, let alone in the classroom interactions.

In addition to this, no study has specifically studied the coherency of the new JHS mathematics curriculum across the different curriculum manifestations: the ideal, the formal, the perceived, and the enacted curriculum as proposed by Goodlad (1979). Goodlad described ideal curriculum as the original assumptions and intensions of the designer; formal curriculum as the concrete curriculum documents; perceived curriculum as the curriculum interpreted by teachers; and enacted curriculum as what actually happens in the classroom in terms of instructional practices. This paper therefore aims at examining the new mathematics curriculum to ascertain its coherence. The paper is therefore guided by the following research questions: 
The importance of theoretical underpinning for a school mathematics curriculum: The Ghanaian experience

a) Is there any difference between the old and the new mathematics curricula?

b) How would coherence be increased by taking an enactivist perspective on the new mathematics curriculum?

The significance of the present study is in two folds: Firstly, the findings from this study provide some useful information regarding the theoretical underpinnings of the new mathematics curriculum and some of the challenges involved in implementing this curriculum. In addition to this, the findings from the study will provide some useful information for mathematics teachers, students and policy makers regarding ways of improving the teaching and learning of mathematics by integrating different theoretical frameworks which no study has specifically done within their Ghanaian context.

\section{A Brief History of Ghana's Junior High School Mathematics Curriculum}

The history of mathematics education in Ghana dates back to colonial era and before independence in 1957 the Ghanaian school mathematics curriculum and the entire school system was modelled after British education system (Kuwayama, Davis, Ampiah, \& Kwabla, 2007). During this period mathematics textbooks and the syllabus used in schools were written by foreigners mostly from the United Kingdom. Some of the mathematics contents studied in secondary schools included factors, multiples, vulgar fractions, percentages, profit and loss, and simple interest. This was in line with the British school curriculum. However, topics such as statistics and probability and set theory which the individual student will need to be able to compare and analysis different situations did not exist in the curriculum (Davis \& Ampiah, 2005).

When Ghana attained independence in 1957, attempts were made to restructure the mathematics curriculum to be consistent with the socio-economic development of the country and make Ghanaian students internationally competitive. Ghanaians began to play an active role in the development of mathematics curricula at all levels of education and; in 1962 the first African Mathematics Program (AMP) was launched in Entebbe in Uganda. Mathematicians from across most African countries including Ghana met to develop new mathematics curricula, syllabi and textbooks to be used at the different levels of their respective education systems (Kuwayama, Davis, Ampiah, \& Kwabla, 2007).

In 1963 a new secondary school mathematics project called the Joint School Project (JSP) program was initiated by members of the Mathematics Association of Ghana (MAG) who worked together with mathematics teachers from selected secondary schools and university teachers to develop and prepare secondary school mathematics curriculum and textbooks (Kuwayama, Davis, Ampiah, \& Kwabla, 2007). The committee completed its work in 1971 and by 1972 the new secondary school mathematics curriculum and textbooks were in use across the country. After the introduction of this first national secondary mathematics curriculum, a number of new mathematics curricula were developed; all with the aim of improving the teaching and learning of the subject. One of these new curricula was the 1988 mathematics curriculum.

The 1988 mathematics curriculum was based on the guidelines of the 1987 educational reform which was aimed at helping students see mathematics as a unified body of knowledge and not as a collection of isolated topics (Davis \& Ampiah, 2005). It was also aimed at helping students develop a mathematical outlook. To achieve this, the curriculum was designed to provide the opportunity for students to understand the world around them in mathematical terms (Davis \& Ampiah, 2005). This was to help students express their ideas in mathematical language, to develop the ability to give clear and correct explanations and to make classifications and generalizations. The 1988 mathematics curriculum was criticized for concentrating more on acquisition of cognitive knowledge rather than assisting students in understanding the utilitarian value of mathematics and applies problem solving approach in solving mathematical problems.

In the year 2001, a new mathematics curriculum was developed and implemented across the country. The 2001 curriculum was designed with the aim of making Ghanaian students competitive at the national and 
Ampadu, E. \& Adofo, S.

international level. To achieve this, the prime objective of the curriculum was to help students develop an interest in mathematics and be active participants in the teaching-learning process (Mereku, 2003). Under the 2001 curriculum students were encouraged to work co-operatively with other students and develop interest in mathematics.

\section{The New Junior High School Mathematics Curriculum}

Despite the numerous changes made to the mathematics curriculum since the introduction of the first curriculum, students' achievements and results were still not at a desirable level. For example, the Ministry of Education (2002) reported students' performance in mathematics over the years gives an indication that the acquisition of basic mathematical concepts emphasized in these curricula has not materialized. In response to these concerns and demands, in January 2002 the Government of Ghana set up a presidential committee to review educational reforms in Ghana. The committee published its report in October 2002, and emphasized the need and ability to make use of recent developments in science and technology, especially Information and Communication Technology (ICT) to enhance teaching and learning. Based on this, the current mathematics curriculum was announced in October 2002 and was implemented in September 2007 as part of the new educational reform, with the view to improving the quality of instruction and increasing its flexibility to accommodate diverse student abilities (Ministry of Education, Science and Sports, 2007).

The new mathematics curriculum for Ghanaian Junior High schools (JHS) which is the focus of this paper is a sixty-six page document which outlines the rationale behind the teaching and learning of mathematics. The curriculum is based on the twin premises that all can learn mathematics and that all need to learn mathematics with a view to achieving a curriculum that reflects individual students' needs. The ultimate goal of the current curriculum is to enable all students to acquire the mathematical skills, insight, attitudes and values needed to be successful in their chosen careers and daily lives by increasing the students' self-oriented learning abilities to the maximum.

\subsection{Key Characteristics of the New Junior High School Mathematics Curriculum}

The aims of the current mathematics curriculum is based on the believe that "strong mathematical competencies developed at the JHS level are necessary requirements for effective study in mathematics, science, commerce, industry and a variety of other professions" (Ministry of Education, Science and Sports, 2007, p. ii). The current curriculum focuses on the student and is designed to help the learner:

$>\quad$ develop the skills to select and apply criteria for classification and generalization

$>$ communicate effectively using mathematical terms, symbols and explanations through logical reasoning

$>\quad$ use mathematics in daily life by recognizing and applying appropriate mathematical problem-solving strategies

$>\quad$ understand the process of measurement and acquire skills in using appropriate measuring instruments

$>\quad$ develop the ability and willingness to perform investigations using various mathematical ideas and operations

$>\quad$ work co-operatively with other students to carry out activities and projects in mathematics and consequently develop the values of cooperation, tolerance and diligence

$>\quad$ use the calculator and the computer for problem solving and investigation of real life situations

$>\quad$ develop an interest in studying mathematics at a higher level in preparation for professions and careers in science, technology, commerce and a variety of work areas 
The importance of theoretical underpinning for a school mathematics curriculum: The Ghanaian experience

The current curriculum is composed of five major areas supported by skills, understanding and attitudes which students need in order to make an informed judgment and apply this knowledge to solve real life problems. The five major areas comprise: numbers and investigation with numbers; geometry, estimation and measurement; algebra; statistics and probability. Numbers covers the reading and writing of numerals in different number bases and the application of the four basic operations: ratio, proportion, percentages, fractions, integers and rational numbers related problems. Investigation with numbers should provide students with the opportunity to discover number patterns and relationships, and to use basic arithmetic operations meaningfully.

Geometry covers the properties of solids, planes and shapes, as well as the relationship between them, whilst estimation and measurement include practical activities to estimate and measure length, area, mass, capacity, volume, angles, time and money. Algebra, which forms the integral part of the curriculum, covers algebraic expressions, relations and functions. The last component of the curriculum, statistics and probability, involves the collection, organization, representation and interpretation of data and an understanding of the fundamental concept of probability and its application in real life situations (Ministry of Education, Science and Sports, 2007). These five areas are further divided into 39 units, of which JHS1 has 15 units, JHS2 has 16 units and JHS3 has 8 units. The organization of the junior high school mathematics curriculum is presented below.

\section{Table 1}

Organization of the new Junior High School Mathematics Curriculum

\begin{tabular}{|c|c|c|c|}
\hline Units & JHS1 & JHS2 & JHS3 \\
\hline Unit 1 & Numbers and Numerals & Numeration systems & Application of Sets \\
\hline Unit 2 & Sets & $\begin{array}{l}\text { Linear equations and } \\
\text { inequalities }\end{array}$ & Rigid motion \\
\hline Unit 3 & Fractions & Angles & Enlargements and Similarities \\
\hline Unit 4 & Shape and Space & $\begin{array}{l}\text { Collecting and Handling } \\
\text { Data }\end{array}$ & Handling data and Probability \\
\hline Unit 5 & Length and Area & Rational numbers & Money and Taxes \\
\hline Unit 6 & Powers of natural numbers & Shape and space & Algebraic expressions \\
\hline Unit 7 & $\begin{array}{l}\text { Introduction to the use of } \\
\text { Calculators }\end{array}$ & Geometric constructions & Properties of Polygons \\
\hline Unit 8 & Relations & Algebraic expressions & Investigations with Numbers \\
\hline Unit 9 & Algebraic expressions & Number Plane & - \\
\hline Unit 10 & $\begin{array}{l}\text { Capacity, Mass, Time and } \\
\text { Money }\end{array}$ & $\begin{array}{l}\text { Properties of } \\
\text { Quadrilaterals }\end{array}$ & - \\
\hline Unit 11 & Integers & Ratio and Proportion & - \\
\hline Unit 12 & Geometric constructions & Mapping & - \\
\hline Unit 13 & Decimal Fractions & Area and Volume & - \\
\hline Unit 14 & Percentages & Rates & - \\
\hline Unit 15 & $\begin{array}{l}\text { Collecting and Handling } \\
\text { Data (Discrete) }\end{array}$ & Probability & - \\
\hline Unit 16 & - & Vectors & - \\
\hline
\end{tabular}

\subsection{Teaching Practices Proposed under the New Mathematics Curriculum}

The current curriculum requires the teacher to:

$>\quad$ create learning situations and provided guided opportunities for students to acquire as much knowledge and understanding through their own activities

$>\quad$ emphasize student centered activities and communication

$>$ foster interest and self-confidence in the learning of mathematics by providing students with opportunities to explore various mathematical situations in their environment to enable them make their own observations and discoveries 
$>\quad$ apply various instructional practices to cater for individual student's needs

$>\quad$ utilize concrete manipulatives to help students to compare, classify, analyze, look for patterns and spot relationship and draw their own conclusions

$>$ consider students evaluation as an integral part of the teaching learning process and evaluation exercises should challenge students to apply the knowledge to issues and problems and engage them in developing solutions and developing investigative skills.

The teaching methods envisioned in the new curriculum and the teacher's guide includes: group work, discovery, investigative and demonstration methods. In general, the new mathematics curriculum encourages teachers to use student-centered approaches in their teaching by avoiding rote learning and drill-oriented methods to achieve optimum student learning. The new curriculum also encourages teachers to emphasize the cognitive, affective and psychomotor domains in their instructional system to help students acquire the capacity for analytical thinking and the capacity for applying their knowledge to problems and real life situations.

\section{Differences between the Old and the New Mathematics Curriculum}

One of the reasons for student's inability to appreciate and apply the mathematics they learn has been attributed to the fact that most students do not understand the utilitarian effect of the concepts they learn (Boaler, 2009). The restructuring of the junior high school mathematics curriculum has been informed by the paradigm shifts in mathematics education over the years. In Ghana, the behaviorist and constructivist theoretical backgrounds have underpinned the restructuring of Ghanaian mathematics curriculum for the past four decades. An analysis of mathematics teaching and learning at the secondary level in Ghana before the introduction of the new curriculum in 2007 shows that classroom practices were characterized by behaviorist tradition of teaching and learning coupled with teacher-centered approaches of teaching (Mereku, 2003; Fletcher, 2005). The 2001 curriculum which was used until 2007 emphasized on the use of discovery teaching methods and other student-centered approaches. However, only few teaching and learning activities that would encourage student-centered teaching were included in the curriculum (Mereku, 2003). The 1987 and the 2001 mathematics curriculum were designed with much emphasis on academic attainment of students with little or no emphasis on the utilitarian effect of mathematical concepts.

As indicated above, the 2007 mathematics curriculum was designed to enable all Ghanaian young people to acquire the mathematical skills, insights, attitudes and values that they will need to be successful in their chosen careers and daily lives (Ministry of Education, Science and Sports, 2007). The new curriculum therefore places emphasis on the acquisition of more skills and variation of teaching methods and resources to help students in developing the mathematical skills that they will need in their daily activities. It also emphasized on a shift from a teacher-centered approach to a more participatory teaching method with time spent on comprehension, application and experimentation as indicated in the content of the mathematics curriculum. The new national mathematics curriculum therefore places emphasis on students playing an active role in the teaching-learning process. It is based on constructivist principles of encouraging students to confront, construct and develop new knowledge by actively taking part in the teaching-learning process through active interaction and participation (Glasersfeld, 1989).

\section{Challenges in Curriculum Implementation}

In spite the innovative changes in the current mathematics curriculum, which reflects the prime aim of changing the teaching and learning of mathematics from teacher-centered to a student-centered approach; the objectives spelt out in the curriculum do not fully match the epistemologies of constructivism. The skills and competencies outlined in the new curriculum still encourages teachers to show, demonstrate and explain things to students and do not differ greatly from the old mathematics curriculum. The current mathematics curriculum therefore only limits the teacher's effect on the teaching and learning process, which suggests that the teacher 
The importance of theoretical underpinning for a school mathematics curriculum: The Ghanaian experience

have to be an active participant rather than a mere facilitator in the classroom. In addition, the majority of the teaching and learning activities outlined in the new curriculum do not differ from those in the old curriculum. Most of these teaching and learning activities fail to make links and use real life situations to demonstrate the numerous mathematical concepts and skills included.

As previously established by other researchers (Fletcher, 2005; Eshun-Famiyeh, 2005; Anamuah-Mensah \& Mereku, 2005; Mereku, 2003) in spite of mathematics teachers desire to apply constructivist teaching and learning practices, most mathematics classrooms in Ghana are characterized by memorization rather than understanding. Ampadu (2012) recently argued that five years after the introduction of the new mathematics curriculum a movement towards a constructivist approach of teaching and learning is not evident in most mathematics classrooms. Students perceptions about the learning of mathematics has still not changed that much. He added that although students experience mathematics differently, the majority experience mathematics in a passive way whereby their experiences are influenced and shaped by their teacher's actions. He further added that although mathematics teachers may possess in-depth knowledge about the national curriculum requirements and the possible changes; its implementation is problematic for some reasons. For example, Pijls, Dekker, and Hout-Wolters (2007) argued that "one of the difficulties for teachers is to observe the learning process or students who are working collaboratively" (p. 309). The implementation of cooperative learning approach, as suggested by constructivist theory, becomes problematic if the teacher doesn't actively take part and sometimes lead the process (Gillies, 2003).

\section{Bridging the Gap - Introducing the Enactivist Theory}

Considering the gaps in the new junior high school mathematics curriculum in relation to the two theoretical backgrounds, it is argued that no one particular theoretical background can facilitate the effective teaching and learning of mathematics. Behaviorism and constructivism introduce the possibility of researching mathematics teaching and learning by combining different theoretical backgrounds. The teaching and learning of mathematics, therefore, goes beyond the ideas of the dichotomies of behaviorism and constructivism. This creates the need to consider an alternative framework for understanding how mathematics is taught and learned, or should be taught and learned, in Ghanaian junior secondary schools.

Learning affects the entire psyche of the individual and this goes beyond cognitive knowing, as emphasized in the constructivist theory which is now the theoretical underpinning of the Ghanaian junior high school mathematics curriculum. While the new mathematics curriculum does not use the term enactivism, the ideas and guidelines presented are more consistent with the principles of enactivism than those of constructivism. This framework is consistent with Dewey's pragmatist philosophy of education, which suggests that teachers and students ought to work together as investigators in the classroom to create new knowledge (Dewey, 1930). According to Dewey (1929), the teacher's role is not to "impose certain ideas or to form certain habits in the child, but...to select the influences which shall affect the child and to assist him in properly responding to these influences" (p. 9). He therefore advocates a teaching method in which teachers and students both participate in educational experiences and the teacher is classified as a natural leader in shared activity because of his/her greater maturity and wider knowledge (Dewey, 1930). This suggests that the teacher does not only acts as a facilitator in the teaching and learning process, but also as a partner who is actively involved in the creation and acquisition of new knowledge in the classroom.

Dewey's ideas regarding the teaching and learning process, the role of the teacher and that of the student in the classroom have, for the past decade, been conceptualized into a new philosophy of pedagogy known as enactivism (Li, 2008; 2010). Enactivism is compatible with elements of Piaget's and Vygotsky's constructivist psychology and is based on the belief that "cognition and environment are inseparable and 'systems' enact with each other from which they learn" (Li, 2008, p.3). Davis, Sumara, and Kierren (1996) defined enactivism as an embodied experience with patterns that shape the individual learner's learning and the creation of new knowledge. Begg (2002) also describes enactivism as an ecological theory that can be considered to be an 
alternative premise to constructivism. He further added that those who hold this theoretical background see learning as a shared activity between the learner and the teacher.

The central idea of enactivism is based on the premise that learners and teachers or educators are co-authors and the classroom discourse is a two way affair and considers the individual as not simply an observer of the world, but as embedded in the world (Davies, Sumara, \& Luce-Kapler, 2000; Reid, Dowden, Jeans, \& d'Entremont, 2000; Li, Clark, \& Winchester, 2010). Learning affects the entire psyche of the individual and this goes beyond cognitive knowing, as emphasized in the constructivist theory which is now the theoretical underpinning of the Ghanaian mathematics curriculum. Proulx (2009) advocated for the introduction of the principles of the enactivist theory in mathematics classrooms because of the complex nature of mathematics teaching and learning, which cannot be examined using only one particular theory.

Enactivism and constructivism may share some seemingly parallel aspects; they are two fundamentally different theoretical perspectives. For example, Reid, Dowden, Jeans, and d'Entremont (2000); Li, Clark, and Winchester (2010) have argued that enactivism, like constructivism, acknowledges the importance of the individual in the construction of a lived world, but emphasizes that the structure of the individual co-emerges with this world in the course of, and as a requirement for, the continuing inter-action of the individual and the situation. "Enactivism as a theory of cognition acknowledges the importance of the individual in the construction of a lived world, but emphasizes that the structure of the individual co-emerges with this world in the course of, and as a requirement for, the continuing inter-action of the individual and the situation" (Reid, Dowden, Jeans, \& d'Entremont, 2000, p. 1). This suggests that the understanding of the individual and how he/she creates or acquires new knowledge is based on schemes of bodily movement and its perceptions (Begg 2002).

The core component of enactivism exemplifies the belief that "the human mind is embodied in our entire organism and embedded in the world, and hence is not reducible to structures inside the head" (Thompson, 2005, p. 408). Enactivism emphasises the fact that the creation of knowledge and the understanding of the world is a shared activity through different systems in order to build a holistic picture of the phenomenon (Davis \& Sumara, 1997; Li, 2008). From an enactivist perspective, the changes in how mathematics is taught and learned are based on the beliefs that learning is "a participation in the world; a co-evolution of the knower and known that transforms both" (Davies, Sumara, \& Luce-Kapler, 2000, p. 64). Classroom practices envisioned by enactivism therefore differ from either the 'adult-run' which is associated with behaviourism or 'children-run' instruction which is associated with constructivism (Rogoff, 1994, p. 210). Learning is not just about gaining information, but is an ongoing process of exploration and interactions with complex systems in order to adapt to the evolving environment (Li, Clark, \& Winchester, 2010). The act of knowing depends upon "the kinds of experience that come from having a particular body plan, schema, or system with a variety of neuronal-sensorimotor abilities, capacities, and functions" (Thompson, 1996, p. 128).

In enactivism, learning occurs when individuals act and interact with each other, changing their behaviour by developing and creating new knowledge together and learning from each other. This suggests that in an enactivist classroom; the teacher does not seek to facilitate nor direct the pupils in what to do and think, but promotes participation and genuine interaction to encourage learning (Proulx, 2009). Teachers are not the source of knowledge in the classroom, but co-authors of knowledge with students by guiding students' attention towards the intended goals (Li, Clark, \& Winchester, 2010). According to Proulx (2009) in the enactivist classroom teachers and students work together to bring forth a world of understanding and this common goal cannot be achieved if the teacher acts as a mere facilitator as proposed by those with a constructivist world view. The role of the teacher is more than that of a mere facilitator, as his/her actions are considered to be triggers for students' learning and this is compatible with a typical classroom situation (Proulx, 2009). This "calls for a teacher that puts oneself within the action and acts vigorously in this learning space to trigger and provoke something in learners" (Proulx, 2009, p. 273). 
The importance of theoretical underpinning for a school mathematics curriculum: The Ghanaian experience

Table 1

Comparisons of Behaviorist, Enactivist and Constructivist Perspectives

\begin{tabular}{|c|c|c|c|}
\hline & Behaviorist Perspective & Enactivist Perspective & Constructivist Perspective \\
\hline Pedagogy & $\begin{array}{l}\text { Transmission approach, } \\
\text { teacher-centered, teachers } \\
\text { present knowledge }\end{array}$ & $\begin{array}{l}\text { Group centered instruction } \\
\text { Embodied }\end{array}$ & $\begin{array}{l}\text { Learner-centered, students } \\
\text { discover and construct } \\
\text { knowledge }\end{array}$ \\
\hline $\begin{array}{l}\text { Knowledge } \\
\text { Acquisition }\end{array}$ & $\begin{array}{l}\text { Knowledge is acquired } \\
\text { Receptive }\end{array}$ & $\begin{array}{l}\text { Knowledge is adopted } \\
\text { Knowledge is enacted }\end{array}$ & $\begin{array}{l}\text { Knowledge is created } \\
\text { Discover and construct new } \\
\text { knowledge }\end{array}$ \\
\hline Assessment & $\begin{array}{l}\text { External standards } \\
\text { Summative tests }\end{array}$ & $\begin{array}{l}\text { Summative tests } \\
\text { Formative tests }\end{array}$ & $\begin{array}{l}\text { Individual standards } \\
\text { Formative tests }\end{array}$ \\
\hline $\begin{array}{l}\text { Role of the } \\
\text { Teacher }\end{array}$ & $\begin{array}{l}\text { Teacher structures learning } \\
\text { tasks } \\
\text { Teacher provides resources } \\
\text { Teacher dominates the } \\
\text { teaching-learning process } \\
\text { Teacher demonstrates } \\
\text { Reactive teachers }\end{array}$ & $\begin{array}{l}\text { Collaborator } \\
\text { Actively guides learning } \\
\text { Active participant in the } \\
\text { teaching-learning process } \\
\text { Guide students towards } \\
\text { co-evolving patterns } \\
\text { Provide rich learning } \\
\text { activities }\end{array}$ & $\begin{array}{l}\text { Teacher structures the } \\
\text { environment } \\
\text { Teacher guides students to } \\
\text { find resources } \\
\text { Teacher observes and } \\
\text { facilitates in the teaching and } \\
\text { learning process } \\
\text { Social interactions structure } \\
\text { learning } \\
\text { Proactive teachers }\end{array}$ \\
\hline $\begin{array}{l}\text { Role of the } \\
\text { Learner }\end{array}$ & $\begin{array}{l}\text { Learner as memorizer } \\
\text { Learner methods } \\
\text { Learn facts } \\
\text { Individual learning }\end{array}$ & $\begin{array}{l}\text { Individual learning } \\
\text { Create meaning } \\
\text { Actors }\end{array}$ & $\begin{array}{l}\text { Learner as a processor } \\
\text { Develop learning strategies } \\
\text { Create meaning } \\
\text { Cooperative learning }\end{array}$ \\
\hline
\end{tabular}

The teacher's active participation in the teaching and learning process is paramount, as there are still some mathematical concepts that the student cannot learn alone and the assistance of a teacher to trigger the students' learning is necessary (Mathews, 1997). The implementation of a real cooperative learning approach, as suggested by constructivist theory, becomes problematic if the teacher doesn't actively take part and sometimes lead the process (Gillies, 2003). Gillies adds that the implementation of cooperative learning strategies, one of the principles of constructivism, is sometime problematic as just putting people in groups does not necessarily lead to effective learning. He further argues that structured cooperative learning that can lead to better learning outcomes and it is only when the teacher structures these groups in such a way as to ensure students understand how they must work that the desired results can be achieved.

\section{Conclusion and Implications}

The paper has presented an overview of the junior high school mathematics curriculum and discusses the need to look beyond the ideas of behaviorism and constructivism due to their numerous limitations and the gaps in the curriculum. Based on this the authors took the position that considering the role that the Ghanaian teacher plays in the teaching-learning process; the principles of constructivism will not necessarily promote effective teaching and learning of mathematics in our classrooms.

As argued by Ampadu (2012) Ghanaian mathematics teachers' are still considered as the custodians of knowledge in most classrooms by students and these students have the impression that their success in mathematics depends on their ability to follow their teacher's instructions and approaches of solving problems. He further added that in a culture where the child mostly relies on an adult for the acquisition of new knowledge and the development of new ideas, the implementation of a constructivist approach is problematic. This suggests that the individual is influenced by the cultural context which in turn, affects their learning process. Therefore the implementation of a constructivist approach of teaching and learning of mathematics, where the teacher acts 
Ampadu, E. \& Adofo, S.

as a facilitator will be problematic in such situations.

The implications drawn from this paper are that inasmuch as teachers and for that matter mathematics teachers try implementing the national curriculum principles, the cultural underpinnings of the Ghanaian society makes it very difficult in fully conceptualizing the concept of constructivism in the classroom. The present study provides mathematics teachers with new ideas in encouraging and stimulating students' active participation in the teaching and learning process. It also provides some valuable information which can be used in helping students in developing independent learning skills. In essence, the results put into question the adaptation of a constructivist approach of teaching and learning of mathematics as indicated in the national curriculum and therefore provide a strong indication that, the adoption and implementation of this policy initiative in the Ghanaian context is problematic.

\subsection{Recommendations}

Therefore, considering the inconsistencies in the new mathematics curriculum, it is proposed that the principles and features of enactivist philosophy provided opportunities for solving these existing inconsistencies in the new mathematics curriculum in Ghana. The authors at this juncture provide the following recommendations as means of improving mathematics teaching and learning in Ghanaian junior secondary schools and Ghana in general.

There is the need to incorporate the principles of enactivism into mathematics lessons

$>\quad$ where the teacher's and the student's inputs are considered as equally important.

Education authorities ought to organize in-service training programs and courses

$>\quad$ for teachers on how to stimulate independent learning among students'.

Likewise, this calls for workshops and guidance sessions for students' on the

$>$ importance of independent learning as a tool for making informed judgment and the

$>$ application of the concepts learnt to real life situations.

Future curriculum restructuring should take into consideration the cultural context of

$>\quad$ the individual student as this goes a long way to affect how they learn.

Likewise, there is the need for consistency in curriculum objectives and the socio-

$>$ economic background of the individual student as these background plays a crucial role in his/her mathematical competencies.

\section{References:}

Ampadu, E. (2013). Aspiring mathematicians: Students' views regarding what it takes to be successful in mathematics. International journal for mathematics teaching and learning. Available online at http://www.cimt.plymouth.ac.uk/journal/ampadu.pdf

Ampadu, E. (2012). An investigation into the teaching and learning of mathematics in junior high schools: The case of Ghana. Unpublished Doctoral dissertation, Anglia Ruskin University, UK.

Anamuah-Mensah, J., \& Mereku, K. D. (2005). On what foundation is Africa building its science and technology base? Africa's participation in TIMSS-2003. African Journal of Educational Studies in Mathematics and Sciences, 3(3), 1-8.

Begg, A. (2002). Enactivism and some implications for education: A personal perspective. Vinculum, 39(2), 4-12. Blum, M. K. (2002). Enhancement of students learning and attitudes towards mathematics through authentic 
The importance of theoretical underpinning for a school mathematics curriculum: The Ghanaian experience

learning experiences. Unpublished Doctoral dissertation, Curtin University of Technology, Australia.

Boaler J. (2009). The elephant in the classroom: Helping children learn and love maths. London: Souvenir Press Ltd.

Davis, E. K., \& Ampiah, J. G. (2005). The history of mathematics education in Ghana. In H. Iwasaki (Ed.), Empirical study on the evaluation method for international cooperation in mathematics education in developing countries-focusing on pupils'Achievement (p. 62-76) Hiroshima University, Hiroshima.

Davis, A. B., Sumara, D. J., \& Kieren, T. E. (1996). Cognition, co-emergence, curriculum. Journal of Curriculum Studies, 28(2), 151-169. http://dx.doi.org/10.1080/0022027980280203

Davis, B., \& Sumara, D. (1997). Cognition, complexity and teacher education. Harvard educational review, 67(1), 105-125.

Davis, B., Sumara, D., \& Luce-Kapler, R. (2000). Engaging minds: Learning and teaching in a complex World. Mahwah, NJ: Lawren Erlbaum Associates.

Dewey, J. (1929). My pedagogic creed. Journal of the national education association, 18(9), 291-295.

Dewey, J. (1930). The duties and responsibilities of the teaching profession. In J. A. Boydston (Ed.), John Dewey: The later works 1925-1953, (vol. 5, pp. 326-330). Carbondale and Edwardsville: Southern Illinois University Press.

Eshun-Famiyeh, J. (2005). Early number competencies of children at the start of formal education. African journal of educational studies in mathematics and sciences, 3(3), 21-31.

Fletcher, J. A. (2005). Constructivism and mathematics education in Ghana. Mathematics Connection, 3, 29-36.

Gillies, R. M. (2003). Structuring cooperative group work in classrooms. International Journal of Educational Research, 39, 35-49. http://dx.doi.org/10.1016/S0883-0355(03)00072-7

Glasersfeld, E. V. (1989). Cognition, construction of knowledge and teaching. Synthesis, 80(1), $121-140$. http://dx.doi.org/10.1007/BF00869951

Goodlad, J. I. (1979). Curriculum inquiry: The study of curriculum practice. New York: McGraw-Hill.

Keith, J. (2000). The student experience of mathematical proof at university level. International Journal of Mathematical Education in Science and Technology, 31(1), 53-60. http://dx.doi.org/10.1080/002073900287381

Kuwayama, H., Davis, E., K., Ampiah, G., J., \& Kwabla, N., F. (2007) International cooperation project towards the endogenous development of mathematics education: Teachers'final report. Hiroshima University, Japan.

Li, Q. (2008). Digital games, CMC, and women: How enactivism help reform E-Learning? Asian Women, 24(4), $1-20$.

Li, Q. (2010). Digital game building: Learning in a participatory culture. Educational Research, 52(4), 427-443. http://dx.doi.org/10.1080/00131881.2010.524752

Li, Q., Clark, B., \& Winchester, I. (2010). Instructional design and technology grounded in enactivism: A paradigm shift? British Journal of Educational Technology, 41(3), 403-419. http://dx.doi.org/10.1111/j.1467-8535.2009.00954.x

Mathews, M. R. (1997). Introductory comments on philosophy and constructivism in science education. Science and Education, 6, 5-14. http://dx.doi.org/10.1023/A:1008650823980

Mereku, D. K. (2003). Methods in Ghanaian primary mathematics textbooks and teachers' classroom practices. In Williams, J. (Ed.) Proceedings of the British society for research into learning mathematics, 23(2), 61-66.

Ministry of Education. (2002). Meeting the challenges of education in the twenty first century: Report of the president's committee on review of education reforms in Ghana. Accra, Ghana.

Ministry of Education, Science and Sports. (2007). Teaching syllabus for mathematics, Accra, Ghana.

Mullis, I. V. S., Martin, O. M., \& Foy, M. P. (2008). TIMSS 2007 International Mathematics Report, Boston: TIMSS and PIRLS international study centre.

Mullis, I. V. S., Martin, O. M., Foy, M. P., \& Arora, A. (2012). TIMSS 2011 international results in mathematics, Boston: TIMSS and PIRLS international study centre.

Nabie, M., J., \& Kolorah-Ekpale, P., T. (2004). Critical analysis of the policy practice of mathematics education 
Ampadu, E. \& Adofo, S.

in Ghana. Mathematics connection, 4, 15-25.

Pijls, M., Dekker, R., \& Hout-Wolters, B., V. (2007). Reconstruction of a collaborative mathematical learning processes. Educational Studies in Mathematics, 65, 309-329.

http://dx.doi.org/10.1007/s10649-006-9051-3

Potari D., \& Georgiadu-Kabouridis B. (2009). A primary teacher's mathematics teaching: The development of beliefs and practice in different "supportive" context. Journal of Mathematics Teacher Education, 12, 7-25. http://dx.doi.org/10.1007/s10857-008-9091-y

Proulx, J. (2009). Some directions and possibilities for enactivism and mathematics education research. In Tzekaki M., Kaldrimidou, M., \& Sakonidis, C., (Eds.) Proceedings of the 33rnd conference of the international group for the psychology of mathematics education (pp. 270-275). Thessaloniki, Greece: PME.

Reid, D. A., Dowden, B., Jeans, S., \& d'Entremont, J. (2000). The psychology of students' reasoning in school mathematics. Wolfville, Nova Scotia, Canada: Acadia University.

Rogoff, B. (1994). Developing understanding of the idea of community of learners. Mind, Culture, and Activity, 1(4), 209-228.

Thompson, E. (1996). The mindful body: Embodiment and cognitive science. In O‘Donovan-Anderson, M., (Ed.), The incorporated self: interdisciplinary perspectives on embodiment (pp. 127-144). Lanham, MD: Rowman and Littlefield.

Thompson, E. (2005). Sensorimotor subjectivity and the enactive approach to experience. Phenomenology and the Cognitive Sciences, 4, 407-427. http://dx.doi.org/10.1007/s11097-005-9003-x

UEW/GES. (2003) Results from Ghanaian junior secondary two students' participation in TIMSS-2003 in mathematics and science. Inspectorate division, MOEYS Accra, Ghana. 